\title{
UJI AKTIVITAS SALEP EKSTRAK ETANOL DAUN JAMBU BIJI (Psidium guajava Linn.) TERHADAP LUKA BAKAR DERAJAT II PADA TIKUS JANTAN PUTIH
}

\author{
Triyani Sumiati*., Devi Ratnasari², Liana Febriyani ${ }^{3}$ \\ 1. Program Studi Farmasi Sekolah Tinggi Teknologi Industri dan Farmasi Bogor \\ 2. Program Studi Farmasi Sekolah Tinggi Teknologi Industri dan Farmasi Bogor \\ 3. Mahasiswa Program Studi S1 Farmasi Sekolah Tinggi Teknologi Industri dan Farmasi Bogor \\ Korespondensi: triyanisumiati@gmail.com
}

\begin{abstract}
ABSTRAK
Tanaman Psidium guajava Linn. yang dikenal dengan nama daun jambu biji merupakan tanaman obat yang telah digunakan untuk mengobati penyakit, termasuk obat luka bakar. Dari hasil penelitian diketahui bahwa ekstrak etanol daun jambu biji dapat menyembuhkan luka bakar. Untuk memudahkan penggunaannya,maka dibuat sediaan salep ekstrak etanol daun jambu biji. Penelitian ini bertujuan untuk membuat formula salep ekstrak etanol daun jambu biji yang memiliki aktivitas penyembuhan pada luka bakar derajat II. Ekstraksi daun jambu biji dilakukan dengan proses maserasi, kemudian ekstrak cair dipekatkan menggunakan rotary evaporator sehingga diperoleh ekstrak pekat daun jambu biji. Formulasi salep ekstrak etanol daun jambu biji dibuat dengan konsentrasi masing masing 30\%, $35 \%$ dan $40 \%$. Uji aktivitas penyembuhan luka bakar derajat II ini menggunakan 5 kelompok, yaitu kontrol negatif (basis salep), kontrol positif, salep ekstrak etanol daun jambu biji konsentrasi 30\%, $35 \%$, dan $40 \%$. Penelitian dilakukan terhadap tikus putih jantan dengan berat antara 200-400 gram. Pengamatan dilakukan sampai hari ke-21. Hasil penelitian dengan menggunakan Uji Tukey menunjukkan bahwa variasi konsentrasi ekstrak daun jambu biji memberikan efek penyembuhan yang tidak berbeda secara nyata terhadap penyembuhan luka bakar derajat II pada tikus putih jantan.
\end{abstract}

Kata kunci : salep, Psidium guajava Linn., etanol, daun jambu biji, luka bakar

\begin{abstract}
Psidium guajava Linn. known as guava leaves is a medicinal plant that has been used to treat diseases, including burns medicine. From the results of the study note that the extract of guava leaves ethanol can heal burns. To facilitate its use, then made ointment preparations of guava ethanol extracts. The purpose of this research is to make an ointment formula ethanol extract of guava leaves which has a healing effectiveness on a second degree burns. Extraction of guava leaf made by the process of maceration, then the liquid extract was concentrated by rotary evaporator to obtain a concentrated extract of guava leaf. An ointment formulations ethanol extract of guava leaf are made with concentrations respectively $30 \%, 35 \%$, and 40 . The effectiveness test of the healing of burns grade II using 5 groups: negative control (ointment base), positive control (Bioplacenton ${ }^{\circledR}$ ), ointments ethanol extract of guava leaves $30 \%, 35 \%$, and $40 \%$. The study was conducted . of male white rats with severe between $200-400$ grams. Observations up to $21^{\text {st }}$ day. These result by using Tukey Test indicate that the concentration of guava leaf extract 35\%, The results of this study indicate that the variation concentration of guava leaf extract gives a healing effect that does not differ significantly to healing second degree burns in male white rats.
\end{abstract}

Keywords : ointments, Psidium guajava Linn., ethanol, guava leaves, burns 


\section{PENDAHULUAN}

Luka bakar adalah kehilangan jaringan yang disebabkan kontak dengan sumber panas seperti api, air panas, bahan kimia, listrik dan radiasi [1]. Luka bakar sering terjadi di rumah dan ditemukan terbanyak adalah luka bakar derajat II. Efek sistemik dan mortalitas yang disebabkan luka bakar sangat ditentukan oleh luas dan dalamnya kulit yang terkena luka [2]. Penanganan dalam penyembuhan luka bakar antara lain mencegah infeksi dan memberi kesempatan sisa-sisa sel epitel untuk berpoliferasi dan menutup permukaan luka [3].

Luka tidak dapat dibiarkan sembuh sendiri karena jika luka tidak dirawat dapat menyebabkan komplikasi penyembuhan luka yaitu dapat tejadi infeksi dan perdarahan. Tujuan merawat luka yaitu untuk mencegah trauma (injury) pada kulit, membran mukosa atau jaringan lain yang disebabkan oleh adanya trauma, fraktur, luka operasi yang dapat merusak permukaan kulit [3]. Percepatan kesembuhan luka yang saat ini banyak dilakukan yaitu dengan cara mempertemukan kedua sisi luka, pemberian obat-obatan seperti salep antibiotik, dibalut dengan teknik tertentu seperti menggunakan hidrogel [3]. Namun, cara penyembuhan itu masih dinilai kurang sederhana oleh sebagian masyarakat sehingga diperlukan alternatif lain untuk menyembuhkan luka selain menggunakan obat khusus maupun antiseptik. Salah satu alternatif lain yang bisa dimanfaatkan yaitu dengan manggunakan daun jambu biji.

Bagian tanaman yang sering digunakan sebagai obat adalah daunnya, karena daunnya diketahui mengandung senyawa tanin, minyak atsiri, flavonoid, dan saponin [4,5]. Tanin bermanfaat sebagai antiseptik dan juga untuk pengobatan luka bakar dengan cara mempresipitasikan protein dan karena ada daya antibakteri $[4,6]$. Daun jambu biji mengandung saponin, flavonoid, tanin dan minyak atsiri. Kandungan saponin, flavonoid serta tanin dapat membantu proses penyembuhan luka karena berfungsi sebagai antioksidan dan antimikroba yang mempengaruhi penyambungan luka juga mempercepat epitelisasi $[7,8]$. Kandungan saponin dan tanin berperan dalam regenerasi jaringan dalam proses penyembuhan luka[9]. Kandungan flavonoid berfungsi sebagai antioksidan, antimikroba dan juga antiinflamasi pada luka bakar $[10,11]$. Kandungan tanin mempercepat penyembuhan luka dengan beberapa mekanisme seluler yaitu membersihkan radikal bebas dan oksigen reaktif, meningkatkan penyambungan luka serta meningkatkan pembentukan pembuluh darah kapiler juga fibroblas.

Dari hasil penelitian Oktiarni et al. (2012), menunjukkan penggunaan ekstrak etanol daun jambu biji dengan variasi konsentrasi $1 \%, 3 \%, 5 \%$ dan $7 \%$ sebagai obat penyembuh luka bakar. Hasil menunjukkan, bahwa pada konsentrasi $1 \%$ memberikan efek penyembuhan sangat nyata (bermakna) pada luka bakar. Namun, hingga saat ini belum ada penelitian untuk menguji khasiat sediaan salep ekstrak daun jambu biji secara topikal terhadap penyembuhan luka bakar derajat II pada tikus putih jantan.

Berdasarkan uraian tersebut menunjukkan bahwa ekstrak etanol daun jambu biji mempunyai potensi untuk dikembangkan menjadi sediaan farmasi sebagai obat herbal penyembuh luka bakar. Pada penelitian ini akan dibuat sediaan farmasi salep dari ekstrak etanol daun jambu biji untuk memudahkan penggunaannya. Salep digunakan untuk pengobatan lokal pada kulit, melindungi kulit pada luka agar tidak terinfeksi serta dapat melembabkan kulit. Untuk tujuan ini, maka akan dibuat sediaan salep ekstrak etanol daun jambu biji dengan basis Vaselin dan Adeps Lanae karena mampu memperpanjang kontak obat dengan kulit, mudah dioleskan, dan memiliki stabilitas baik.

\section{METODE PENELITIAN}

Bahan: Bahan - bahan yang digunakan pada penelitian ini adalah ekstrak etanol daun jambu biji (Psidium guajava Linn.) yang diperoleh dari perkebunan di Kabupaten Cianjur , salep Bioplasenton ${ }^{\circledR}$, adeps lanae, vaselin album, Dinatrium EDTA, Metil Paraben, Propil Paraben, aquadest, alkohol $70 \%$, Pereaksi Mayer (1,36 gram $\mathrm{HgCl}_{2}, 5$ gram KI, dan Air sampai $100 \mathrm{ml}$ ), Pereaksi Wagner (2,5 gram iodin, 2 gram kalium iodida dan Air sampai $200 \mathrm{ml}$ ) , Pereaksi Dragendorff (8 gram $\mathrm{Bi}\left(\mathrm{NO}_{3}\right)_{3} \cdot \mathrm{H}_{2} \mathrm{O}, 30 \% \mathrm{~b} / \mathrm{v} \mathrm{HNO} 3,27,2$ gram KI, Air sampai $100 \mathrm{ml})$, Pereaksi Buchar $(1 \mathrm{ml}$ asam asetat anhidrat, $1 \mathrm{ml}$ kloroform, 1 tetes 
asam sulfat pekat), besi (III) klorida, asam asetat anhidrat, $\mathrm{H}_{2} \mathrm{SO}_{4}$ pekat, $\mathrm{NH}_{3}, \mathrm{CHCl}_{3}, \mathrm{HCl}$ pekat serbuk magnesium $(\mathrm{Mg}), \mathrm{FeCl}_{3}$, dan Eter.

Alat: Alat-alat yang digunakan dalam penelitian ini adalah alat-alat gelas, batang pengaduk, blender, plat tetes, waterbath, cawan porselen, kassa steril, mortir dan stemper, sudip, kertas saring,timbangan analitik, pencukur bulu, kandang, jangka sorong/penggaris, ayakan mess no.65, rotary evaporator, kapas, thermometer, alat penginduksi panas, dan wadah salep, $\mathrm{pH}$ meter.

Hewan Uji: Hewan uji yang digunakan dalam penelitian ini adalah tikus putih jantan (Rattus norvegicus) dewasa galur Sprague dawley dengan usia 3-4 bulan yang memiliki berat 200 - 400gram. Diadaptasikan selama 7 hari sebelum perlakuan serta diberi pakan berjenis pur 512 .

\section{Metode \\ Preparasi Sampel}

Sampel yang digunakan adalah daun jambu biji (Psidium guajava Linn.) Sampel daun jambu biji segar yang berwarna hijau dibersihkan atau disortasi, kemudian dicuci dengan air mengalir hingga bersih. Sampel daun sirsak dikeringkan dengan dianginanginkan selama 3-5 hari. Sampel dihaluskan dengan blender serta diayak dengan pengayak ukuran 60 mesh.

\section{Penentuan Kadar Air}

Pengerjaannya dilakukan dengan cara cawan porselin dikeringkan pada suhu $105^{\circ} \mathrm{C}$ selama 3 jam, kemudian didinginkan dalam eksikator selama 30 menit dan ditimbang untuk mengetahui bobot kosong dari cawan. Sebanyak 2 gram sampel dimasukkan ke dalam cawan porselin dan dimasukkan ke dalam oven pada suhu $105^{\circ} \mathrm{C}$ selama 6 jam, kemudian didinginkan dan ditimbang kembali. Rumus perhitungan kadar air, sebagai berikut:

$$
\text { Kadar air }(\%)=\frac{a-b}{a} \times 100 \%
$$

$\mathrm{a}=$ bobot sampel sebelum pemanasan $(\mathrm{g})$

$\mathrm{b}=$ bobot sampel setelah pemanasan $(\mathrm{g})$

\section{Pembuatan Ekstrak Etanol Daun Jambu Biji}

Serbuk simplisia daun jambu biji sebanyak 100 gram, dimasukkan ke dalam labu erlenmeyer. Selanjutnya dilakukan maserasi dengan menggunakan pelarut etanol $70 \%$ (1:10). Ekstraksi dengan pelarut tersebut menggunakan metode maserasi selama $3 \times 24$ jam. Setiap 24 jam hasil maserasi (maserat) ini selanjutnya disaring dengan menggunakan kertas saring dan diambil filtratnya, kemudian ditambah lagi pelarut etanol 70\% sampai 3 kali ulangan. Selanjutnya ekstrak disaring menggunakan corong butcher untuk memisahkan residu dengan filtrat. Filtrat yang diperoleh selanjutnya dipekatkan dengan menggunakan rotary evaporator pada suhu $60^{\circ} \mathrm{C}$.

Ekstrak kental yang diperoleh kemudian dihitung $\%$ rendemennya dengan rumus:

$$
\text { Rendemen }=\frac{\text { bobot ekstrak kental }}{\text { bobot serbuk }} \times 100 \%
$$

Selanjutnya esktrak kental yang diperoleh kemudian diencerkan menjadi 3 macam konsentrasi untuk empat perlakuan, yaitu $30 \%, 35 \%$, dan $40 \%$.

\section{Uji Fitokimia[7]}

a. Uji Alkaloid

Sebanyak 500mg ekstrak etanol daun jambu biji diuapkan di atas cawan porselin. Residu yang dihasilkan kemudian dilarutkan dengan $5 \mathrm{~mL} \mathrm{HCl} 2 \mathrm{~N}$. Larutan yang diperoleh dibagi ke dalam 3 tabung reaksi.

Pada tabung pertama dimasukkan pereaksi Mayer, hasil dinyatakan (+) jika terbentuk endapan putih. Pada tabung kedua dimasukkan perekasi Dragendorff, hasil dinyatakan (+) bila terbentuk endapan merah jingga. Pada tabung ketiga dimasukkan pereaksi Wagner, hasil dinyatakan (+) bila terbentuk endapan coklat.

b. Uji Flavonoid

Sebanyak $500 \mathrm{mg}$ ekstrak etanol daun jambu biji dilarutkan dalam $5 \mathrm{ml}$ air kemudian dipanaskan selama 5 menit setelah itu disaring. Filtrat ditambahkan serbuk magnesium serta HCl:etanol (1:1) dan amil alkohol. Hasil dinyatakan positif bila terbentuk endapan warna jingga hingga merah ungu.

c. Uji Saponin 
Sebanyak $500 \mathrm{mg}$ ekstrak etanol daun jambu biji ditambahkan $5 \mathrm{ml}$ akuades dalam tabung reaksi. Dikocok kuat-kuat, adanya saponin ditandai dengan terbentuk busa yang stabil.

d. Uji Tanin

Sebanyak $500 \mathrm{mg}$ sampel (ekstrak etanol $96 \%$, ekstrak etil asetat, dan ekstrak nheksan) direbus dengan $10 \mathrm{ml}$ akuades dalam tabung reaksi selama 5 menit, kemudian disaring. Filtrat ditetesi $\mathrm{FeCl}_{3}$ $1 \%$. Uji positif ditandai dengan munculnya warna hijau kecoklatan atau biru kehitaman.

e. Uji Steroid dan Triterpenoid

Sebanyak 500mg ekstrak etanol daun jambu biji ditambahkan etanol kemudian dipanaskan selama 2 menit. Residu dilarutkan dengan $0,5 \mathrm{ml}$ kloroform, kemudian ditambahkan $0,5 \mathrm{ml}$ asam asetat anhidrat. Ditambahkan asam sulfat pekat sebanyak $2 \mathrm{ml}$ melalui dinding tabung. Terbentuk cincin kecoklatan atau violet pada perbatasan larutan menunjukkan adanya triterpenoid, sedangkan apabila muncul cincin biru kehijauan menunjukkan adanya steroid.

\section{Pembuatan Sediaan Salep}

Sediaan salep yang akan dibuat dalam penelitian ini memiliki konsentrasi ekstrak daun jambu biji yaitu 30\%, 35\%, dan $40 \%$. Dibuat sebanyak 20 gram dari masing-masing konsentrasi.

Proses pembuatan salep diawali dengan memasukan Adeps lanae dan Vaselin album kedalam lumpang kemudian diaduk hingga homogen. Setelah basis salep tersebut homogen, ditambahkan Dinatrium EDTA, metil paraben dan propil paraben kedalam lumpang yang berisi basis salep sambil diaduk hingga homogen. Selanjutnya ditambahkam ekstrak daun jambu biji sedikit demi sedikit dan terus diaduk hingga homogen dan membentuk salep.

Tabel 1. Modifikasi Formulasi Salep Ekstrak Etanol Daun Jambu Biji

\begin{tabular}{lccc}
\hline \multicolumn{1}{c}{ Bahan } & \multicolumn{3}{c}{ Konsentrasi } \\
\hline Ekstrak Daun Jambu Biji & $30 \%$ & $35 \%$ & $40 \%$ \\
Dinatrium EDTA & $0,1 \%$ & $0,1 \%$ & $0,1 \%$ \\
Metil Paraben & $0,1 \%$ & $0,1 \%$ & $0,1 \%$ \\
Propil Paraben & $0,05 \%$ & $0,05 \%$ & $0,05 \%$ \\
Adeps Lanae & $10,46 \%$ & $9,71 \%$ & $8,96 \%$ \\
Vaselin & $59,29 \%$ & $55,04 \%$ & $50,79 \%$ \\
\hline Total & $100 \%$ & $100 \%$ & $100 \%$
\end{tabular}

\section{Persiapan Hewan Uji}

Hewan uji yang digunakan dalam penelitian ini adalah tikus putih jantan dewasa jantan galur Sprague Dawley dengan berat badan 200-400 gram sebanyak 30 ekor. Besar sampel dihitung dengan rumus Federer (1963), dalam Laksmi (2013) :

Keterangan :

$$
\begin{aligned}
& \mathrm{n}=\text { jumlah pengulangan } \\
& \mathrm{t}=\text { jumlah perlakuan }
\end{aligned}
$$

Rumus Federer didapatkan pengulangan :

$$
\begin{aligned}
(\mathrm{n}-1) \times(5-1) & >15 \\
(\mathrm{n}-1) \times(4) & >15 \\
\mathrm{n} & >4,75
\end{aligned}
$$

minimal jumlah sampel $=5$
Berdasarkan hasil perhitungan di atas, jumlah sampel tikus putih yang digunakan pada penelitian ini adalah 5 ekor per kelompok. Karena jumlah kelompok adalah 5, maka jumlah tikus putih seluruhnya adalah 25 ekor, kemudian diadaptasikan selama kurang lebih 7 hari. Dalam penelitian digunakan 5 kelompok hewan uji yaitu Kelompok kontrol positif, Kelompok kontrol negaif, Kelompok Konsentrasi ekstrak etanol daun jambu biji $30 \%, 35 \%$, dan $40 \%$.

\section{Pembuatan Luka Bakar}

Sehari sebelum pengujian, seluruh kelompok tikus putih ditimbang bobotnya. Kemudian tikus putih dicukur bulu di daerah tubuh yang akan dibuat luka bakar pada bagian punggung kanan. Sebelum dibuat luka, tikus dianastesi dengan menggunakan eter sebanyak 5-8 ml. Panaskan solder listrik 
(electro cauter) yang ujungnya dimodifikasi dengan logam aluminium berdiameter $2,5 \mathrm{~cm}$. Kemudian dibuat luka bakar derajat II dengan solder listrik (electro cauter) pada kulit tikus yang sudah disterilkan terlebih dahulu dengan alkohol $70 \%$ selama 2 detik tanpa menggunakan tekanan sehingga hanya bagian kulit epidermis yang terluka.

\section{Uji Aktivitas Sediaan Salep Daun Jambu Biji}

Pengujian aktivitas sediaan salep ekstrak daun jambu biji (Psidium guajava Linn.) dilakukan pada seluruh kelompok tikus yang sudah dilukai dengan diameter $2,5 \mathrm{~cm}$. Kemudian luka bakar diolesi salep Bioplasenton $^{\circledR}$ (kontrol positif), basis salep (kontrol negatif), dan salep ekstrak daun jambu biji 30\%, 35\%, dan 40\%. Masing-masing diolesi secukupnya pada luka bakar derajat II. Perlakuan dilakukan sehari sebanyak 2 kali. Kulit punggung tikus diamati selama 21 hari.

\section{Analisa Data}

Data yang akan dianalisis yaitu persentase penyembuhan luka bakar yang diperoleh melalui pengukuran rata-rata diameter luka bakar. Pengukuran dilakukan satu kali setiap hari. Pengukuran rata-rata diameter luka bakar dilakukan dengan menggunakan rumus: $\mathrm{dx}=\frac{d 1+d 2+d 3}{d}$ untuk rata-rata diameter luka bakar $(\mathrm{cm})$ dari setiap hewan uji.

Keterangan:

$$
\begin{array}{ll}
\mathrm{d}_{\mathrm{x}(1,2)} & =\text { rata-rata diameter luka bakar } \\
& \text { setiap ulangan perlakuan }(\mathrm{cm}) \\
\mathrm{d} 1, \mathrm{~d} 2, \mathrm{~d} 3 & =\text { perlakuan ke-1, ke-2, ke-3 } \\
\mathrm{d} & =\text { banyaknya perlakuan }(\mathrm{cm})
\end{array}
$$

Sedangkan persentase penyembuhan luka bakar dihitung dengan rumus :

$$
P \%=\frac{(\text { d.luka awal }- \text { d.luka akhir })}{\text { d.luka awal }} \times 100 \%
$$

Keterangan :

$\mathrm{P} \%=$ Persentase penyembuhan luka $(\%)$

d. luka awal $=$ diameter luka awal $(\mathrm{cm})$

d. luka akhir $=$ diameter luka pada hari pengamatan $(\mathrm{cm})$

\section{HASIL DAN PEMBAHASAN Pembuatan Simplisia}

Sampel yang digunakan pada penelitian ini adalah daun jambu biji (Psidium guajava Linn.) Simplisia daun jambu biji dibuat serbuk dan diayak dengan pengayak 60 mesh. Setelah pengayakan, serbuk daun jambu biji diukur kadar airnya. Penentuan kadar air berguna untuk mengetahui batasan maksimal atau kisaran kandungan air dalam bahan. Hal ini berhubungan dengan daya simpan simplisia, sehingga jika melebihi batas yang ditentukan sangat mempengaruhi waktu kadaluarsa dari simplisia tersebut. Semakin tinggi kadar air, maka semakin mudah ditumbuhi jamur dan kapang sehingga dapat menurunkan aktivitas biologi senyawa aktif selama penyimpanan. Jumlah kadar air yang baik pada daun, yaitu $\leq 10 \%[10]$.

Hasil penetapan kadar air yang diperoleh pada penelitian ini adalah 12,80\% Nilai kadar air daun jambu biji ini dapat disebabkan karena dalam struktur daun jambu biji terdapat zat kutin pada kutikula yang berfungsi mencegah penguapan air melalui permukaan daun.

\section{Hasil Ekstraksi Daun Jambu Biji}

Sampel daun jambu biji diekstraksi dengan tujuan untuk memisahkan komponen kimia yang terdapat pada daun jambu biji. Metode ekstraksi yang digunakan pada penelitian ini, yaitu maserasi dengan menggunakan pelarut etanol $70 \%$. Pemilihan metode maserasi dikarenakan maserasi merupakan metode yang paling mudah dan sederhana, tidak memerlukan peralatan yang khusus serta suhu yang yang digunakan rendah sehingga dapat mencegah penguraian senyawa yang tidak tahan panas. Etanol $70 \%$ bersifat polar, sehingga diharapkan mampu menyari senyawa polar seperti tanin, dan flavonoid. Penggunaan etanol sebagai pelarut disebabkan karena etanol bersifat polar sehingga dapat menarik senyawa-senyawa polar seperti flavonoid, saponin, tanin dan lain-lain. Ekstrak yang diperoleh dari hasil ekstraksi ini dipekatkan dan dihasilkan ekstrak kental. Persen rendemennya adalah $8,40 \%$.

\section{Hasil Uji Fitokimia Ekstrak Etanol Daun Jambu Biji}

Uji fitokimia dalam penelitian ini dilakukan bertujuan menganalisis keberadaan senyawa yang diduga memiliki aktivitas 
penyembuh luka bakar pada kulit. Penapisan dilakukan terhadap golongan senyawa alkaloid, flavonoid, saponin dan tanin. Hasil uji fitokimia terhadap ekstrak etanol daun jambu biji menunjukkan hasil positif pada uji flavonoid dan tanin. Sedangkan pada uji alkaloid, saponin, steroid, dan triterpenoid menunjukkan hasil negatif yang ditandai dengan tidak adanya perubahan warna.

Flavonoid merupakan metabolit sekunder yang terdapat pada vakuola tanaman. Pada penelitian ini, diduga bahwa flabvanoid dan tanin yang mempunyai peran dalam mengobati adanya luka bakar pada kulit.

Tabel 2.Hasil uji fitokimia

\begin{tabular}{lcl}
\hline \multicolumn{1}{c}{ Zat Aktif } & Hasil & \multicolumn{1}{c}{ Keterangan } \\
\hline Alkaloid & - & 1. Mayer $\quad$ 2. Tidak terbentuk endapan putih \\
& + & Warna hijau kehitaman \\
Flavonoid & + & Warna hijau kecoklatan \\
Tanin & + & Tidak Terbentuk busa \\
Saponin & - & Tidak ada perubahan warna coklat kemerahan \\
Steroid & - & Tidak terbentuk cincin warna merah \\
Triterpenoid & - & $(+):$ Positif, mengandung zat aktif \\
\hline Keterangan : & $(-):$ Negatif, tidak mengandung zat aktif
\end{tabular}

\section{Hasil Pembuatan Salep Ekstrak Daun Jambu Biji}

Salep yang dibuat merupakan sediaan setengah padat, bau khas ekstrak daun jambu biji, dan memiliki warna coklat muda. Salep ekstrak daun jambu biji dibuat dengan menggunakan basis vaselin album sebagai dasar salep hidrokarbon. Pemilihan vaselin sebagai basis salep dimaksudkan untuk memperpanjang kontak bahan obat (zat aktif) dengan kulit dan bertindak sebagai pembalut (penutup). Adeps lanae digunakan sebagai dasar salep absorbs. Adeps lanae berfungsi sebagai emolien yang digunakan untuk mencegah atau mengurangi kekeringan sebagai perlindungan bagi kulit. Dinatrium EDTA ditambahkan sebagai bahan pengkompleks dan berfungsi sebagai penstabil. Metil Paraben dan Propil Paraben digunakan sebagai bahan pengawet.

Sesuai aturan pembuatan salep, dimana zat-zat yang dapat larut dalam campurancampuran lemak dilarutkan kedalamnya, sehingga vaselin dan adeps lanae dicampurkan langsung ke dalam lumpang dan diaduk hingga homogen. Setelah itu ditambahkan metil paraben dan propil paraben lalu ditambahkan dinatrium EDTA. Ekstrak daun jambu biji ditambahkan terakhir karena bentuk sediaan berupa ekstrak kental. Hal ini dimaksudkan untuk mendapatkan sediaan yang homogen.

\section{Hasil Pengamatan Penyembuhan Luka Bakar Derajat}

Luka bakar biasanya dinyatakan dengan derajat yang ditentukan oleh kedalaman luka bakar, walaupun demikian berat luka bergantung pada dalam, luas, daerah luka, umur, dan kesehatan penderita. Luka bakar derajat II merupakan kerusakan yang terjadi pada seluruh bagian epidermis dan sebagian lapisan dermis, berupa reaksi inflamasi disertai proses eksudasi. Penyembuhan luka bakar derajat II akan terjadi selama 3 minggu (21 hari).

Pengukuran diameter untuk kelompok perlakuan pada hari ke-1 sampai hari ke-21, dapat dilihat pada gambar 1. Pada hari ke-0 untuk semua perlakuan masih berwarna putih terbakar dan belum terlihat adanya perubahan karena belum diberikan perlakuan, untuk hari ke-1 perubahan sedikit terlihat, pada hari ke-3 sampai hari ke-10 terbentuk krusta (koreng) pada bagian yang terbakar. Perubahan terjadi pada hari ke-11 sampai hari ke-16 krusta (koreng) terlepas dari kulit dan mulai terlihat penyempitan pada luka bakar, sedangkan penyembuhan terjadi pada hari ke-19 sampai hari ke-21 dimana diameter luka mulai menyempit dan masih ada sedikit bekas luka yang terlihat pada kulit. 


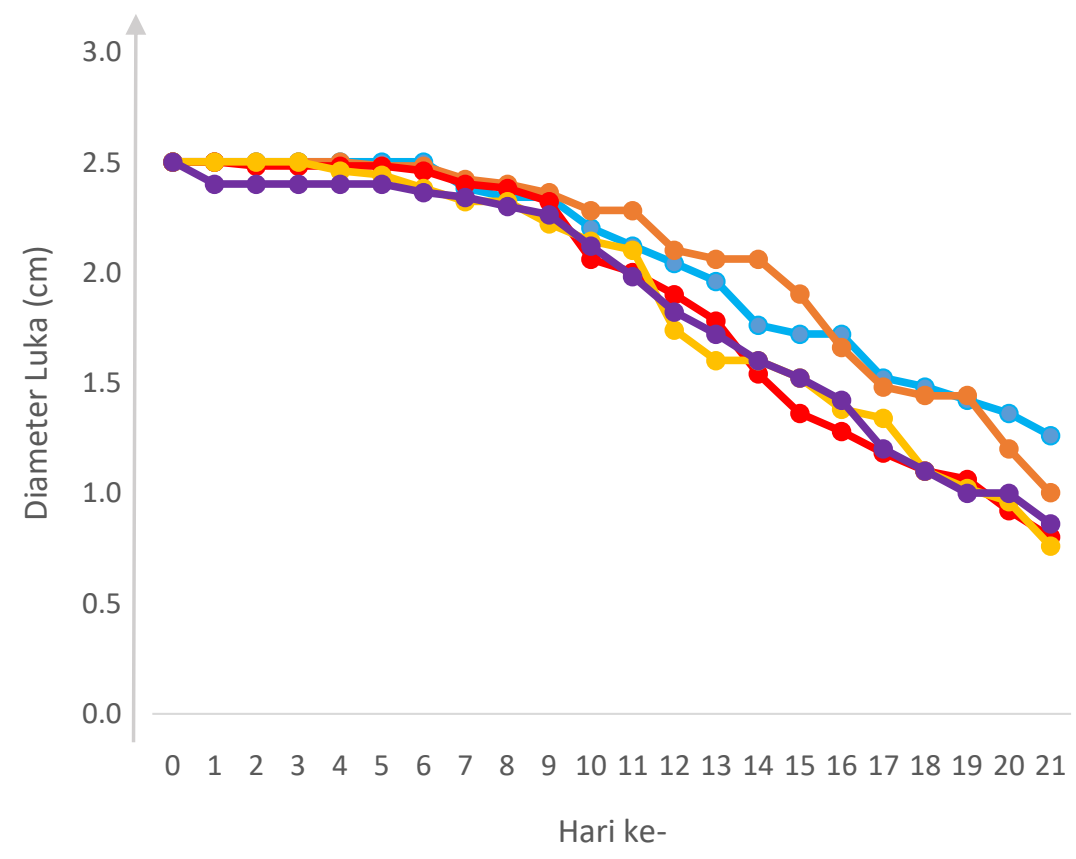

Gambar 1. Diagram Penurunan Diameter Luka Rata-rata Pada Penyembuhan Luka Bakar Keterangan : - Kontrol negatif $(\mathrm{Kn})$ - Kontrol positif $(\mathrm{Kp})$ - Ekstrak daun jambu biji 30\%

— Ekstrak daun jambu biji 35\% — Ekstrak daun jambu biji 40\%

Pada kelompok kontrol negatif, hewan uji yang diamati mengalami penyembuhan luka. Penyembuhan ditandai dengan mengecilnya diameter luka bakar, artinya tubuh yang sehat mempunyai kemampuan alami untuk melindungi dan memulihkan dirinya sehingga penyembuhan luka tetap terjadi. Pada tabel 3 dapat dilihat adanya penurunan rata-rata diameter luka bakar setelah 21 hari. Selanjutnya Persentase kesembuhan luka dianalisis dengan menggunakan prosedur pembandingan Tukey dengan tingkat kepercayaan 95\%, menampilkan notasi huruf yang sama yaitu A untuk setiap perlakuan. Hal ini dapat disimpulkan bahwa seluruh konsentrasi salep ekstrak etanol daun jambu biji menghasilkan perubahan yang relatif sama (tidak berbeda nyata) pada proses penyembuhan luka bakar, tidak ada perbedaan yang bermakna pada penurunan diameter akhir pada luka bakar II.

Tabel 3. Persentase Penyembuhan Luka Bakar

\begin{tabular}{lccc}
\hline Sediaan Salep & $\begin{array}{c}\text { Rata-rata diameter luka } \\
\text { awal }(\mathbf{c m})\end{array}$ & $\begin{array}{c}\text { Rata-rata diameter } \\
\text { luka akhir }(\mathbf{c m})\end{array}$ & $\begin{array}{c}\text { P\% (Persentase } \\
\text { penyembuhan luka) }\end{array}$ \\
\hline Kontrol Positif & 2,50 & 1,00 & 60,00 \\
Kontrol Negatif & 2,50 & 1,26 & 49,60 \\
$\begin{array}{l}\text { Ekstrak daun } \\
\text { jambu 30\% }\end{array}$ & 2,50 & 0,80 & 68,00 \\
$\begin{array}{l}\text { Ekstrak daun } \\
\text { jambu 35\% }\end{array}$ & 2,50 & 0,76 & 69,60 \\
$\begin{array}{l}\text { Ekstrak daun } \\
\text { jambu 40\% }\end{array}$ & 2,50 & 0,86 & 65,60 \\
\hline
\end{tabular}

\section{SIMPULAN}

Berdasarkan hasil penelitiaan yang telah dilakukan dapat disimpulkan bahwa ekstrak air daun jambu biji mengandung flavonoid, dan tanin. Hasil uji invivo salep ekstrak etanol daun jambu biji 30\%, 35\%, dan 40\% dapat memberikan aktivitas penyembuhan luka bakar derajat II pada kulit punggung tikus putih jantan. Tidak ada perbedaan nyata pada semua konsentrasi ekstrak etanol daun jambu biji pada proses penyembuhan luka bakar. 


\section{SARAN}

Perlu dilakukan penelitian lebih lanjut untuk mendapatkan dosis optimal ekstrak etanol daun jambu biji yang bermanfaat pada proses penyembuhan luka.

\section{DAFTAR PUSTAKA}

[1] Moenadjat Y. 2003. Luka Bakar: Pengetahuan Klinik Praktis. Edisi ke2. Jakarta: Balai Penerbit FKUI

[2] Ollstein, R.N. 1996. Luka Bakar. Dalam Keterampilan Pokok Ilmu Bedah. Edisi Keempat. T.F. Nealon dan W.H. Nealon. Buku Kedokteran. Jakarta: EGC.

[3] Syamsuhidayat, dan Jong, W., 1997. Buku Ajar Ilmu Bedah. Edisi Revisi. Jakarta: EGC.

[4] Oktiarni, D., Syalfinaf, M., Supripno. 2012. Pengujian Ekstrak Daun Jambu Biji (Psidium guajava Linn.) Terhadap Penyembuhan Luka Bakar Pada Mencit (Mus musculus). [SKRIPSI]. Bengkulu MIPA Gedung T Universitas Bengkulu.

[5] Atmaja, N. D. 2007. Aktivitas Antioksidan Fraksi Eter dan Air Ekstrak Metanolik Daun Jambu biji (Psidium guajavaLinn.) terhadap Radikal Bebas 1,1-difenil 2pikrilhidrazil (DPPH) [Skripsi]. Surakarta:Fakultas Farmasi. USB.

[6] Masduki. 1996 . Efek Antibakteri Ekstrak Biji Pinang (Areca catechu) Terhadap S.aureus dan E.coli in vitro. Cermin Dunia Kedokteran. Hal. 23-24.
[7] Senthil P, Kumar AA, Manasa M, Kumar KA, Sravanthi K, and Deepa D. Wound Healing Activity of Alcoholic Extract of "Guazuma ulmifolia" Leaves on Albino Wistar Rats. International Journal of Pharma and Bio Sciences. 2011; 2(4): 34-38

[8] Saroja M, Santhi R and Annapoorani S. Wound Healing Activity of Flavonoid Fraction of Cynodon dactylon in Swiss Albino Mice. International Research Journal of Pharmacy. 2012; 3(2): 230231.

[9] Reddy BK, Gowda S, and Arora AK. Study of Wound Healing Activity of Aqueous and Alcoholic Bark Extracts of Acacia catechu on Rats. RGUHS Journal of Pharmaceutical Sciences. 2011; 1(3): 220-225

[10] Harborne, 1996. Metode Fitokimia Penuntun Cara Modern Menganalisis Tumbuhan. Terbitan kedua. Terjemahan K. Padmawinata dan 1. Soediro. Bandung: ITB.

[11] Park et al. Protection of Burn-Induced Skin Injuries by the Flavonoid Kaempferol. BMB Reports. 2010; 43(1): 46-51. 
